\title{
Desenvolvimento de um dispositivo para obter plasma rico em plaquetas (PRP)
}

\section{Development of a Device to Obtain Platelet-Rich Plasma (PRP)}

\author{
Marília de Lima Mota ${ }^{10}$ Ronald Bispo Barreto ${ }^{2}$ \\ Beatriz Costa Cardoso Dourado Cavalcante ${ }^{10}$

\footnotetext{
1 Universidade Tiradentes, Murilo Dantas, Aracaju, SE, Brasil

2 Faculdade de Medicina, Universidade Tiradentes, Murilo Dantas, Aracaju, SE, Brasil
}

\author{
Bárbara Ramos Leite ${ }^{1(\mathbb{C}}$
}

\begin{abstract}
Endereço para correspondência Marília de Lima Mota, Acadêmica de Medicina, Universidade Tiradentes, Rua Acre, 313, Aracaju, Sergipe, 49075-020, Brasil (e-mail: mariliadelimamota@gmail.com).
\end{abstract}

\section{Resumo}

\section{Palavras-chave}

- dispositivo

- plaquetas

- plasma rico em plaquetas
Objetivo Apresentar um dispositivo inovador que aplique o método de centrifugação dupla para obter plasma rico em plaquetas (PRP), avaliando se houve um aumento efetivo na concentração de plaquetas.

Método Dez voluntários foram submetidos a coleta de sangue. As amostras foram separadas em seringas de $20 \mathrm{~mL}$, seladas e submetidas ao protocolo de centrifugação dupla a 1.100 revoluções por minuto (rpm) por 15 minutos, resultando na separação de hemácias, plasma com plaquetas e leucócitos. Em seguida, foram adicionadas seringas de $10 \mathrm{~mL}$ para remover $9 \mathrm{~mL}$, tendo como parâmetro a "buffy coat", coletando $8 \mathrm{~mL}$ acima e $1 \mathrm{~mL}$ abaixo para a segunda centrifugação e transferindo novamente para a seringa de $20 \mathrm{~mL}$. O plasma foi novamente centrifugado a $1.550 \mathrm{rpm}$ por 10 minutos; como resultado, foi dividido em duas partes: na parte superior, consistindo em plasma pobre em plaquetas (PPP), e na parte inferior, pelo botão plaquetário. Parte do PPP foi descartada, restando apenas $3 \mathrm{~mL}$ com o botão de plaquetas. As células foram então contadas.

Resultados Este dispositivo inovador foi capaz de aumentar a concentração de plaquetas em quase 3 vezes relação a linha de base. Além disso, o tempo de preparo do PRP foi adequado, com duração de apenas 35 a 40 minutos.

Conclusões O PRP foi obtido com sucesso pelo protocolo de centrifugação dupla, permitindo seu uso clínico. Além disso, a obtenção através do dispositivo apresentado promove maior aplicabilidade no preparo do PRP em centros específicos, além de ser, uma forma rápida e econômica de obter PRP.

Trabalho desenvolvido na Universidade Tiradentes, Murilo Dantas, Aracaju, SE, Brasil.

recebido 16 de Maio de 2020 aceito

17 de Setembro de 2020

Publicado on-line

Março 31, 2021
DOI https://doi.org/ 10.1055/s-0040-1721835. ISSN 0102-3616. (c) 2021. Sociedade Brasileira de Ortopedia e Traumatologia. All rights reserved.

This is an open access article published by Thieme under the terms of the Creative Commons Attribution-NonDerivative-NonCommercial-License, permitting copying and reproduction so long as the original work is given appropriate credit. Contents may not be used for commercial purposes, or adapted, remixed, transformed or built upon. (https://creativecommons.org/ licenses/by-nc-nd/4.0/)

Thieme Revinter Publicações Ltda., Rua do Matoso 170, Rio de Janeiro, RJ, CEP 20270-135, Brazil 


\begin{abstract}
Keywords

- device

- platelet

- platelet-rich plasma

Objective To present an innovative device that applies the double centrifugation method to obtain platelet-rich plasma (PRP), assessing whether there was an effective increase in the concentration of platelets.

Method Ten volunteers underwent blood collection. The samples were separated in $20 \mathrm{ml}$ syringes, sealed and subjected to the double centrifugation protocol at 1,100 revolutions per minute (rpm) for 15 minutes, resulting in the separation of red blood cells, plasma with platelets, and leukocytes. Then, $10 \mathrm{ml}$ syringes were added to remove $9 \mathrm{ml}$, respecting the "buffy coat" parameter, collecting $8 \mathrm{ml}$ above and $1 \mathrm{ml}$ below for the second centrifugation and transferring again to the $20 \mathrm{ml}$ syringe. The plasma was again centrifuged at 1,550 rpm for 10 minutes; as a result, it was divided into two parts: at the top, consisting of low platelet plasma (LPP), and at the bottom, by the platelet button. Part of the LPP was discarded, leaving only $3 \mathrm{ml}$ with the platelet button. The cells were then counted.

Results This innovative device was able to increase the concentration of platelets by almost three times compared with the baseline. In addition, the preparation time for the PRP was adequate, lasting only 35 to 40 minutes.

Conclusions Platelet-rich plasma was successfully obtained by the double centrifuge protocol, allowing its clinical use. In addition, obtaining through the presented device promotes greater applicability in the preparation of PRP in specific centers, furthermore, being a quick and economical way to obtain PRP.
\end{abstract}

\section{Introdução}

O plasma rico em plaquetas (PRP), devido à sua capacidade regenerativa em diferentes tecidos, é considerado uma tecnologia com grande potencial. A ação local de fatores de crescimento, os resultados na diferenciação e proliferação celular, bem como a modulação na resposta inflamatória, são algumas das razões biológicas para seu uso clínico. ${ }^{1}$ O PRP é definido como um volume de plasma com mais plaquetas do que o encontrado no sangue periférico. ${ }^{2} \mathrm{~A}$ literatura mais recente opta por uma definição mais quantitativa, e acredita-se que uma concentração de plaquetas entre $200 \times 10^{3}$ e $1000 \times 10^{3} / \mu \mathrm{L}$ é considerada terapeuticamente eficaz, enquanto concentrações mais elevadas seriam biologicamente desfavoráveis. ${ }^{3-5}$ Estudos desenvolvidos no campo da ortopedia apontam para o uso promissor do PRP. Sánchez et al. ${ }^{6}$ demonstraram que, após 6 meses de tratamento da osteoartrite do quadril com PRP, houve diminuição da intensidade da dor em $40 \%$ dos pacientes. Mishra et al. ${ }^{7}$ avaliaram o efeito do PRP no tratamento da tendinose crônica do cotovelo, observando uma redução da dor, além de uma alternativa terapêutica antes da intervenção cirúrgica. Sánchez et al. ${ }^{8}$ trataram pacientes com ruptura do tendão de Aquiles com PRP. Em seu estudo, os atletas tratados apenas com cirurgia foram comparados aos tratados com PRP e cirurgia. Observou-se que os tratados com cirurgia e PRP apresentaram melhora da cicatrização e recuperação funcional. O PRP também tem sido utilizado em cirurgias ortopédicas, como substituição total da articulação e correção de defeitos osteocondrais por artroscopia. ${ }^{9,10}$

O PRP é obtido do sangue do paciente por meio de um processo que utiliza separação celular por centrifugação, que pode ser classificada como centrifugação única ou dupla.
Embora não haja consenso sobre qual delas seria a mais vantajosa para obter PRP, Macedo ${ }^{11}$ demonstrou que a centrifugação dupla tem maior capacidade de concentração de plaquetas. Em seu estudo, ao analisar dois protocolos, observou que a contagem de plaquetas aumentou $143 \%$ com a centrifugação única, ao passo que com a centrifugação dupla apresentou um aumento de $327 \%$. A obtenção de PRP pelos diversos protocolos existentes na literatura é objeto de interesse, pois pode resultar em compostos de diferentes concentrações de plaquetas. ${ }^{12}$

Um estudo de Perez et al., ${ }^{13}$ que usou 3,5 $\mathrm{mL}$ de sangue e força centrífuga de $100 \mathrm{G}$ durante 10 minutos em uma primeira centrifugação, e de $400 \mathrm{G}$ durante 10 minutos na segunda centrifugação, resultou em uma concentração 5 vezes maior de plaquetas. Kececi et al. ${ }^{14}$ utilizaram, como protocolo para a primeira centrifugação, parâmetros de 250 a $270 \mathrm{G}$ durante 10 minutos; na segunda centrifugação, a força variou para 300 G, 500 G, 750 G, 1000 G, 1500 G e 2000 G durante 10 minutos. A concentração de plaquetas acompanhou o aumento da força durante a segunda centrifugação, aumentando 1,92 vezes, 2,16 vezes, 2,80 vezes, 3,48 vezes, 3,67 vezes e 3,76 vezes, respectivamente. Assim, concluiu-se que a obtenção de uma certa concentração de plaquetas pode ser possivelmente ajustada, individualmente, de acordo com a força de centrifugação utilizada. Como visto, as diferentes concentrações de plaquetas obtidas dependem do protocolo utilizado, dificultando a avaliação de qual o melhor para obter o PRP.

$O$ presente estudo teve como objetivo apresentar um dispositivo inovador para a preparação de PRP, composto por um conjunto de peças adaptáveis às seringas de uso comum, que por sua vez são adaptáveis à centrífuga, acelerando o tempo de preparo e reduzindo a chance de ativação de plaquetas. Esta é uma alternativa de baixo custo. Além 
disso, testamos sua eficácia através de um protocolo de centrifugação dupla para produção de PRP, avaliando o aumento efetivo da concentração de plaquetas.

\section{Material e Métodos}

\section{Seleção de pacientes}

O processo de preparação do PRP foi realizado no UnitLab da Universidade Tiradentes (Unit), Campus Farolândia, Aracaju, SE. O presente estudo foi aprovado pelo Comitê de Ética em Pesquisa sob o parecer número 3.801.134. Dez voluntários, entre 18 e 70 anos, participaram do estudo após passarem por consulta médica em ambulatório de ortopedia. Nenhum dos participantes usou anticoagulantes orais, nem apresentou sintomas gripais nos últimos 30 dias de coleta. Além disso, foram incluídos no presente estudo apenas aqueles que possuíam plaquetas sanguíneas totais $>50.000 / \mu \mathrm{L}$ e que não manifestaram nenhum tipo de discrasia sanguínea.

\section{Método de Obtenção de PRP}

Primeiro, com uma seringa de $20 \mathrm{~mL}$, aspiramos $1 \mathrm{~mL}$ do frasco contendo o anticoagulante citrato ácido dextrose (ACD). Em seguida, após a antissepsia da região antecubital com algodão encharcado de álcool, foi realizada punção venosa de $14 \mathrm{~mL}$ de sangue de cada voluntário com a seringa de $20 \mathrm{~mL}$, agitando suavemente para unir o anticoagulante ao sangue (-Fig. 1A). Uma amostra de $3 \mathrm{~mL}$ foi separada em um tubo estéril para determinar a contagem inicial de plaquetas. A seringa de $20 \mathrm{~mL}$ foi utilizada no processo de centrifugação dupla para obter o PRP em uma centrífuga de laboratório com um molde que permitiu sua fácil adaptação (- Fig. 1B). As seringas de $20 \mathrm{~mL}$ foram levadas para uma centrífuga e, com a tampa fechada, submetidas a 1,100 revoluções por minuto $(224 \mathrm{G})$ por 15 minutos, dando origem a 3 colunas devido a diferenças na densidade dos componentes sanguíneos: a inferior, vermelha,

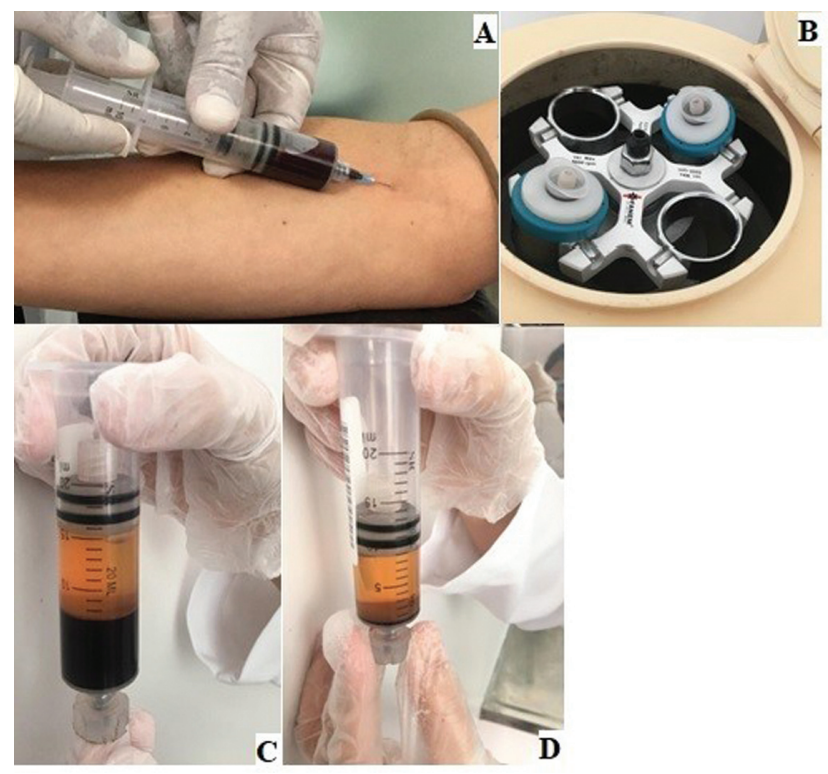

Fig. 1 Imagens da preparação do plasma rico em plaquetas (PRP). (A) Posicionamento da venipuntura. (B) Centrífuga adaptada utilizada para obter o PRP. (C) Amostra de sangue após primeira centrifugação. (D) Amostra de sangue após segunda centrifugação. com hemácias; e a superior, amarela, com plasma e plaquetas. Entre essas duas colunas está uma faixa estreita esbranquiçada, conhecida como "buffy coat", que tem glóbulos brancos e plaquetas concentradas (-Fig. 1C). Dos $15 \mathrm{~mL}$ contidos na seringa de $20 \mathrm{~mL}, 8 \mathrm{~mL}$ foram removidos acima da zona de neblina e $1 \mathrm{~mL}$ abaixo dela, totalizando $9 \mathrm{~mL}$. Estes $9 \mathrm{~mL}$ foram submetidos a uma nova centrifugação de 1.550 revoluções por minuto (rpm) (444 G) por 10 minutos, dando origem a duas colunas: a superior, formada por plasma pobre em plaquetas (PPP); e a inferior, pelo botão eritrócito-plaquetário (-Fig. 1D). $O$ volume de $6 \mathrm{~mL}$ que corresponderia ao PPP foi aspirado com uma seringa de $10 \mathrm{~mL}$, descartando-a, deixando $3 \mathrm{~mL}$ ao lado do botão eritrócito-plaquetário. Este material foi lentamente agitado para permitir a ressuspensão plaquetária, resultando em PRP. Após este método para obtenção de PRP, os $3 \mathrm{~mL}$ foram transferidos para um tubo estéril e a contagem de plaquetas foi realizada em um dispositivo automático.

\section{Análise Estatística}

A análise dos dados foi realizada utilizando-se o teste t de Student para variáveis dicotômicas e o coeficiente de correlação de Pearson para categorias, com nível de significância de $5 \%$ ( $p<0,05)$. O software utilizado foi o IBM SPSS Statistics for Windows, versão 25.0 (IBM Corp., Armonk, NY, EUA).

\section{Resultados}

O perfil sociodemográfico dos voluntários é mostrado a seguir (-Tabela $\mathbf{1}$ ).

\section{Contagem de plaquetas após aplicação do protocolo}

Nas amostras de sangue dos 10 voluntários, a quantidade inicial de plaquetas estava dentro dos parâmetros normais (200.000385.000 plaquetas $/ \mu \mathrm{L}$ ). Após a centrifugação dupla dos $14 \mathrm{mLde}$ amostras de sangue, obtivemos um valor médio de 694.200 plaquetas $/ \mu \mathrm{L}$ (desvio padrão $[\mathrm{DP}]=57.019$ plaquetas $/ \mu \mathrm{L}$ ). A contagem de plaquetas obtida inicialmente e posteriormente à aplicação do protocolo de concentração de plaquetas usando este novo dispositivo se encontra na -Tabela 2.

Este protocolo de centrifugação dupla levou a um aumento na contagem de plaquetas de pelo menos 2 vezes em relação ao valor inicial de plaquetas na amostra de sangue. Os valores médios das plaquetas antes e depois da aplicação do nosso protocolo para obtenção de PRP são mostrados na = Figura 2.

\section{Contagem de outras células após a aplicação do protocolo}

Ao analisar os valores de hemoglobina (HB), hematócrito (HCT), leucócitos (LEUCO) e neutrófilos (NEUTRO), observouse uma redução de $25,12 \%$ no valor do HB e de $24,1 \%$ no valor

Tabela 1 Dados dos voluntários

\begin{tabular}{|l|l|l|}
\hline & Feminino & Masculino \\
\hline Sexo & 8 & 2 \\
\hline Idade média & 29,30 \\
\hline Índice de massa corporal médio & 25,7783 \\
\hline
\end{tabular}


Tabela 2 Resultados da contagem inicial de plaquetas e após aplicação do protocolo de obtenção do PRP

\begin{tabular}{|l|l|l|l|}
\hline Voluntário & $\begin{array}{l}\text { Contagem inicial de } \\
\text { plaquetas }\left(\mathbf{x} \mathbf{0}^{3} \text { plaquetas } / \mu \mathrm{L}\right)\end{array}$ & $\begin{array}{l}\text { Contagem de plaquetas no } \\
\text { PRP }\left(\mathbf{x} 10^{3} \text { plaquetas } / \mu \mathrm{L}\right)\end{array}$ & $\begin{array}{l}\text { Aumento na contagem de } \\
\text { plaquetas }\left(\mathbf{x} 10^{3} \text { plaquetas/ } \mu \mathrm{L}\right)\end{array}$ \\
\hline $\mathbf{1}$ & 291 & 595 & 304 \\
\hline $\mathbf{2}$ & 224 & 623 & 399 \\
\hline $\mathbf{3}$ & 291 & 849 & 558 \\
\hline $\mathbf{4}$ & 222 & 549 & 327 \\
\hline $\mathbf{5}$ & 266 & 760 & 494 \\
\hline $\mathbf{6}$ & 200 & 507 & 307 \\
\hline $\mathbf{7}$ & 318 & 673 & 355 \\
\hline $\mathbf{8}$ & 385 & 829 & 444 \\
\hline $\mathbf{9}$ & 339 & 717 & 378 \\
\hline $\mathbf{1 0}$ & 283 & 840 & 557 \\
\hline Média & 281,9 & 694,2 & 412,3 \\
\hline
\end{tabular}

Abreviação: PRP, plasma rico em plaquetas.

Plaquetas $\mu / L(x 103)$

Linha de base média valor médio no PRP

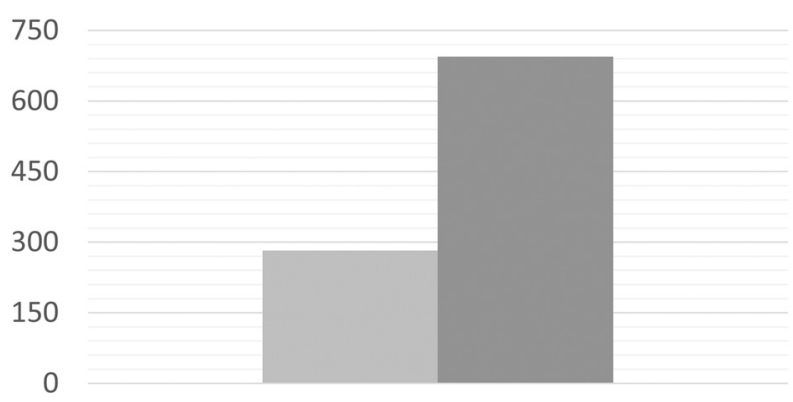

Fig. 2 Resultado após aplicação do protocolo de obtenção de plasma rico em plaquetas (PRP), promovendo um aumento na contagem média de plaquetas de pelo menos o dobro do valor inicial.

de HCT. Em relação ao LEUCO e NEUTRO, houve aumento de $104,98 \%$ e de $72,58 \%$, respectivamente.

\section{Algumas correlações}

Houve correlação entre a quantidade final de plaquetas e a quantidade de hemoglobina basal $(p=0,023)$. Além disso, o aumento percentual das plaquetas tem maior média entre os homens (169,5\%), e não houve correlação significativa em relação à idade, peso ou índice de massa corporal (IMC).

Preservação de plaquetas e tempo para obtenção de PRP $O$ volume de ACD usado na conservação de plaquetas foi de $1 \mathrm{~mL}$. A obtenção do PRP, desde a fase inicial com aspiração anticoagulante à obtenção de PRP, durou de 35 a 40 minutos.

\section{Discussão}

Na literatura, as aplicações clínicas do PRP são diversas; envolvem lesões cutâneas, ósseas, dentárias, oftalmológicas, lesões nervosas, queimaduras, cirurgias vasculares e estéticas, além de lesões tendinosas, musculares e de cartilagens. Os resultados encontrados foram otimistas e promissores na maioria dos estudos. No entanto, é difícil escolher o método a ser utilizado devido a inúmeras alternativas de protocolos para obtenção de PRP e a padronização ausente entre eles, o que pode justificar a falta de eficácia observada por alguns autores. ${ }^{15}$ Os métodos descritos para a obtenção de PRP podem ser divididos em dois grupos: centrifugação e aférese. Um estudo de Malavolta et al. ${ }^{16}$ analisou o uso de PRP obtido através de aférese no reparo artroscópico de rompimento completo do manguito rotador, mostrando que está associado a uma melhora funcional significativa e sem rompimento completo. Por este método, $\sim 400 \mathrm{~mL}$ de sangue foram drenados em um dispositivo de separação sob centrifugação contínua a $5.800 \mathrm{rpm}$ por 15 minutos, através de um acesso periférico. Após a separação dos elementos sanguíneos por densidade, um analisador ótico determinou a camada plaquetária pela característica de sua refração e a separou em um saco de coleta estéril, obtendo cerca de $30 \mathrm{~mL}$ de PRP; os outros componentes sanguíneos foram devolvidos através do mesmo acesso venoso. A aférese, embora possa gerar maiores concentrações de plaquetas em comparação com a centrifugação, não é um método prático e menos caro como a centrifugação. Assim, utilizando a centrifugação, o presente estudo apresenta um método menos oneroso e altamente prático para a preparação do PRP, juntamente com um protocolo que visa garantir uma eficácia mínima do produto final. 0 sangue puncionado para formulação do PRP foi adicionado à seringa contendo o $\mathrm{ACD}$, que tem maior capacidade de concentração de plaquetas quando comparado a outros anticoagulantes, como citrato de sódio (SC). ${ }^{17} \mathrm{O}$ uso de anticoagulantes é importante pois, ao se ligarem ao cálcio, impedem o início da cascata de coagulação, impossibilitando a transformação de protrombina em trombina. É importante ressaltar que o uso de um anticoagulante não é de fato obrigatório na criação do PRP; no entanto, em sua ausência, a cascata de coagulação começará em torno de 30 segundos a vários minutos. ${ }^{3}$ A escolha do ACD no presente estudo visa preservar plaquetas, evitando mudanças em sua estrutura e funcionalidade. 
A contagem inicial de plaquetas foi pelo menos 2 vezes menor do que a presente após a preparação do PRP. As conclusões do presente trabalho estão em consonância com as apresentadas por Nagata et al., ${ }^{18}$ nas quais a quantidade final de plaquetas no PRP foi substancialmente maior do que a contagem de plaquetas da amostra de sangue inicial. Além disso, Franco ${ }^{19}$ também obteve valores semelhantes ao avaliar a eficácia do PRP após artroplastia total do joelho. Um volume de $20 \mathrm{~mL}$ de sangue periférico foi coletado e centrifugado a $1.200 \mathrm{rpm}$ durante 10 minutos. O plasma (a camada mais superficial) foi transferido para outro tubo estéril de $10 \mathrm{~mL}$ e centrifugado na mesma rotação durante 5 minutos. Ao final, metade da camada de plasma superior obtida foi descartada, deixando um concentrado de plaquetas com duas a quatro vezes o valor do plasma. O estudo apontou que, embora o PRP não tenha sido eficaz na redução do sangramento ou na melhora da função do joelho após a artroplastia, houve uma melhor resposta na avaliação da dor após 24 e 48 horas, 1 e 3 semanas e 2 meses após a operação $(p<0,05)$. Em relação ao método de centrifugação, pode ser centrifugação única ou dupla. O presente estudo optou pelo protocolo de centrifugação dupla, recomendado por Landesberg et al. ${ }^{20}$ e Garcez et al., ${ }^{21}$ tendo se mostrado eficaz, com aumento de ao menos $100 \%$ no número de plaquetas. Também houve aumento na quantidade de plaquetas próximo a $200 \%$, possibilitando a obtenção de resultados ainda mais favoráveis. Além disso, a centrifugação dupla mostrou-se superior em estudo comparando ambos os métodos. Um volume de $8,5 \mathrm{~mL}$ de sangue foi submetido a $1.300 \mathrm{rpm}$ por 10 minutos e, para uma segunda centrifugação, $2.000 \mathrm{rpm}$ por 10 minutos. Na centrifugação única, o volume foi de 3,5 mL, com parâmetros de $1.500 \mathrm{rpm}$ por 7 minutos. Ao final, houve um aumento de $336 \%$ no número de plaquetas com a centrifugação dupla e de $227 \%$ com a única. ${ }^{22}$ O PRP é mais difícil e caro quando obtido por métodos automatizados que requerem kits exclusivos, os quais necessitam de quantidades maiores de sangue, a fim de obter uma concentração de plaquetas adequada e grandes volumes de PRP. ${ }^{23,24}$

Após inúmeros estudos em busca do método de coleta mais adequado vinculado ao de menor custo, como os de Weibrich et al. ${ }^{25}$ e de Vendramin et al. ${ }^{23}$, que originaram protocolos para o preparo de PRP usando centrífugas de laboratório, o presente estudo foi realizado para desenvolver um novo dispositivo para a obtenção de PRP, cujo método é simples, rápido e de baixo custo. Embora um protocolo de centrifugação ainda não tenha sido produzido, alguns estudos sugerem uma centrifugação única, enquanto outros indicam centrifugação dupla. ${ }^{20,26-28}$ Como não há consenso quanto ao número de centrifugações (única ou dupla) e a velocidade de rotação e tempo estabelecido, este protocolo padronizou a centrifugação dupla para obter PRP, garantindo o dobro da contagem inicial de plaquetas no sangue periférico. Uma velocidade de $1.100 \mathrm{rpm}$ foi usada durante 15 minutos na primeira centrifugação, e $1.550 \mathrm{rpm}$ durante 10 minutos na segunda. A escolha da centrifugação dupla deveu-se à sua aplicabilidade em estudos com resultados promissores, como o uso de PRP adjuvante para o tratamento da pseudoartrose tibial. Por meio de punção de acesso periférico, $55 \mathrm{~mL}$ de sangue foram coletados e passaram por uma primeira centrifugação de $3.650 \mathrm{rpm}$ por 12 minutos, descartando a camada de eritrócitos, sendo o restante submetido a uma segunda centrifugação de $3.000 \mathrm{rpm}$, onde dois terços superiores do PPP foram descartados e o resto foi misturado com concentrado trombótico, produzindo PRP. Neste estudo, o uso de PRP levou a um menor tempo de consolidação ( 7 meses) em comparação aos 13 meses em pacientes que não o utilizaram $(p>0,01) .{ }^{29}$ Um estudo realizado por Denieli ${ }^{30}$ também reforça a escolha pela centrifugação dupla, no qual foi avaliado o efeito da aplicação cirúrgica de PRP em lesões condrais do joelho. Um total de $20 \mathrm{~mL}$ de sangue foi puncionado em veia periféricae centrifugado a $1.200 \mathrm{rpm}$ por 10 minutos. A camada mais superficial (plasma) foi utilizada, descartando a "buffy coat" e as hemácias, na segunda centrifugação por 5 minutos na mesma velocidade. Após a segunda centrifugação, a metade inferior (PRP) foi utilizada para aplicação, observando resultados melhores e mais rápidos da funcionalidade em comparação com aqueles que não utilizaram o PRP. Esses resultados já aparecem 3 meses após a cirurgia e duram até 12 meses.

O presente trabalho obteve um aumento na contagem inicial de plaquetas entre $104,47 \%$ e $196,82 \%$ por meio do protocolo de centrifugação dupla e da aplicação das velocidades mencionadas. Embora alguns autores afirmem que o número de plaquetas contidas no PRP deve ser $>1.000 .000$ plaquetas $/ \mu \mathrm{L}$, outros afirmam que é possível obter um efeito terapêutico com um valor mínimo de 300.000 plaquetas $/ \mu L^{31}$ No presente trabalho, foi alcançada uma contagem final de plaquetas no PRP entre 507.000 e 849.000 plaquetas $/ \mu \mathrm{L}$, semelhante à literatura. ${ }^{32} \mathrm{O}$ tempo de preparação para o PRP no presente estudo, desde a coleta do anticoagulante antes da venipuntura até a obtenção, foi de 35 a 40 minutos. 0 tempo é um fator crucial quando se considera o uso de PRP em procedimentos cirúrgicos. Quanto à duração para obtenção do PRP, o presente estudo mostrou semelhanças com os de Garcez et al. ${ }^{33}$ e Morato et al., ${ }^{34}$ que observaram uma variação de 30 a 50 minutos neste tempo.

Vários dispositivos para preparação de PRP estão disponíveis comercialmente, os quais operam a partir de um pequeno volume sanguíneo coletado $(20-60 \mathrm{~mL})$ e usam o protocolo de centrifugação única ou dupla. Variando o método e o tempo de centrifugação para a preparação do PRP, esses sistemas diferem em relação ao seu potencial de concentração de plaquetas. Como efeito, há variação na quantidade de plaquetas presentes no PRP. Assim, torna-se complexo avaliar qual kit seria o melhor para a obtenção do PRP. ${ }^{35}$ PRGF (BTI Biotechnology Institute, Porto, Portugal), Harvest SmartPReP (Harvest Technologies Corporation, Viena, Áustria), Vivostat (Vivostat A/S, Copenhague, Dinamarca) e Regen (Regenlab, Lausanne, Suíça) são alguns dos sistemas automatizados comercializados para preparação de PRP; no entanto, são caros e difíceis de manusear, o que pode levar à esterilidade comprometida por um operador inexperiente ou a uma qualidade inconstante.

\section{Conclusões}

As conclusões apresentadas no presente estudo indicam que a obtenção do PRP pelo dispositivo apresentado, seguindo o 
protocolo de centrifugação, é de excelente aplicabilidade em centros específicos que atuam na produção de PRP, além de ser uma forma fácil e econômica de prepará-lo. Usando o método de centrifugação dupla, obtivemos um aumento significativo na contagem de plaquetas no PRP em comparação a quantidade inicial de plaquetas no sangue periférico. Além disso, a obtenção do PRP leva aproximadamente 35 a 40 minutos, o que pode ser considerado um tempo aceitável e rápido.

\section{Suporte Financeiro}

Não houve suporte financeiro de fontes públicas, comerciais, ou sem fins lucrativos.

\section{Conflito de Interesses}

Os autores não têm conflito de interesses a declarar.

\section{Referências}

1 Conde-Montero E, Horcajada-Reales S, Suárez-Fernández R. Utilidad del plasma rico en plaquetas en el tratamiento de las úlceras crónicas de la piel. Piel (Barc) 2014;29(04):248-254

2 Fitzpatrick J, Bulsara MK, McCrory PR, Richardson MD, Zheng MH. Analysis of Platelet-Rich Plasma Extraction: Variations in Platelet and Blood Components Between 4 Common Commercial Kits. Orthop J Sports Med 2017;5(01):2325967116675272

3 Marx RE. Platelet-rich plasma (PRP): what is PRP and what is not PRP? Implant Dent 2001;10(04):225-228

4 Mazzocca AD, McCarthy MB, Chowaniec DM, et al. Platelet-rich plasma differs according to preparation method and human variability. J Bone Joint Surg Am 2012;94(04):308-316

5 Mazzucco L, Balbo V, Cattana E, Guaschino R, Borzini P. Not every PRPgel is born equal. Evaluation of growth factor availability for tissues through four PRP-gel preparations: Fibrinet, RegenPRP-Kit, Plateltex and one manual procedure. Vox Sang 2009;97(02):110-118

6 Sánchez M, Guadilla J, Fiz N, Andía I. Ultrasound-guided plateletrich plasma injections for the treatment of osteoarthritis of the hip. Rheumatology (Oxford) 2012;51(01):144-150

7 Mishra A, Pavelko T. Treatment of chronic elbow tendinosis with buffered platelet-rich plasma. Am J Sports Med 2006;34(11): 1774-1778

8 Sánchez M, Anitua E, Azofra J, Andía I, Padilla S, Mujika I. Comparison of surgically repaired Achilles tendon tears using platelet-rich fibrin matrices. Am J Sports Med 2007;35(02):245-251

9 Anitua E, Andia I, Ardanza B, Nurden P, Nurden AT. Autologous platelets as a source of proteins for healing and tissue regeneration. Thromb Haemost 2004;91(01):4-15

10 Sánchez M, Azofra J, Anitua E, et al. Plasma rich in growth factors to treat an articular cartilage avulsion: a case report. Med Sci Sports Exerc 2003;35(10):1648-1652

11 Macedo A. Plasma Rico em Plaquetas: Uma análise quantitativa e qualitativa de dois protocolos de obtenção [tese]. Florianópolis. Santa Catarina: Universidade Federal de Santa Catarina; 2004

12 Yazigi Junior JA, Dos Santos JB, Xavier BR, Fernandes M, Valente SG, Leite VM. Quantification of platelets obtained by different centrifugation protocols in SHR rats. Rev Bras Ortop 2015;50(06):729-738

13 Perez AG, Lana JF, Rodrigues AA, Luzo AC, Belangero WD, Santana $\mathrm{MH}$. Relevant aspects of centrifugation step in the preparation of platelet-rich plasma. ISRN Hematol 2014;2014:176060

14 Kececi Y, Ozsu S, Bilgir O. A cost-effective method for obtaining standard platelet-rich plasma. Wounds 2014;26(08):232-238

15 Borzini P, Mazzucco I. Platelet-rich plasma (PRP) and platelet derivatives for topical therapy. What is true from the biologic view point? ISBT Sci Ser 2007;2(01):272-281
16 Malavolta E, Gracitelli M, Sunada E, et al. Plasma rico em plaquetas no reparo artroscópico das roturas completas do manguito rotador. Rev Bras Ortop 2012;47(06):741-747

17 Carmona J, Ríos E, Vilar J, Giraldo C, López C. Efectos de dos anticoagulantes sobre el conteo celular y parámetros de activación plaquetaria de plasma rico en plaquetas de bovinos. Arch Med Vet 2014;46(03):375-380

18 Nagata MJ, Melo LG, Messora MR, et al. Effect of platelet-rich plasma on bone healing of autogenous bone grafts in critical-size defects. J Clin Periodontol 2009;36(09):775-783

19 Franco B. Estudo randomizado da enxertia de plasma rico em plaquetas para consolidação da pseudoartrose da tíbia em relação aos tratamentos convencionais [tese]. Araraquara: Universidade Estadual Paulista; 2019

20 Landesberg R, Roy M, Glickman RS. Quantification of growth factor levels using a simplified method of platelet-rich plasma gel preparation. J Oral Maxillofac Surg 2000;58(03):297-300, discussion 300-301

21 Garcez T, Mello H, Mörschbacher P, et al. Liquid and Gel Platelet Rich Plasma as Skin Healing Adjuvant. Acta Sci Vet 2018;44(01):7

22 Tamimi FM, Montalvo S, Tresguerres I, Blanco Jerez L. A comparative study of 2 methods for obtaining platelet-rich plasma. J Oral Maxillofac Surg 2007;65(06):1084-1093

23 Vendramin F, Franco D, Nogueira C, Pereira M, Franco T. Plasma rico em plaquetas e fatores de crescimento: técnica de preparo e utilização em cirurgia plástica. Rev Col Bras Cir 2006;33(01):24-28

24 Carmona J. Use of autologous platelet concentrates for the treatment of musculoskeletal injuries in the horse [thesis]. Bellaterra: Universitat Autònoma de Barcelona; 2006

25 Weibrich G, Kleis WK, Hitzler WE, Hafner G, Hafner G. Comparison of the platelet concentrate collection system with the plasma-richin-growth-factors kit to produce platelet-rich plasma: a technical report. Int J Oral Maxillofac Implants 2005;20(01):118-123

26 Venturelli A. Regeneción ósea: plasma rico en plaquetas. Rev Asoc Odontol Argent 1999;87(06):459-467

27 Bezerra F, Lenharo A. Terapia clínica avançada em implantodontia. São Paulo: Artes Médicas; 2002

28 Sonnleitner D, Huemer P, Sullivan DY. A simplified technique for producing platelet-rich plasma and platelet concentrate for intraoral bone grafting techniques: a technical note. Int J Oral Maxillofac Implants 2000;15(06):879-882

29 Guerreiro J, Danieli M, Queiroz A, Deffune E, Ferreira R. Plasma rico em Plaquetas (PRP) aplicado na artroplastia total do joelho. Rev Bras Ortop 2015;50(02):186-194

30 Denieli M. Lesão condral do joelho: Comparação entre ressonância magnética e vídeo-artroscopia. Efeito da aplicação do plasma rico em plaquetas [tese]. Botucatu: Universidade Estadual Paulista; 2016

31 Del Carlo R, Monteiro B, Argolo N, Serakides R. Microscopic aspects of repair mediated platelet rich plasma and cancellous autograft in experimental bone defects in the skull of rabbits. Vet Anim 2009;16(01):152-160

32 Carmona J, López C, Prades M. Uso de concentrados autólogos de plaquetas obtenidos mediante el método del tubo como tratamiento de artropatías en caballos. Arch Med Vet 2009;41(02): 175-179

33 Garcez T, Paz A, Magrisso A, et al. Comparação entre três protocolos de obtenção de plasma rico em plaquetas (PRP) utilizando coelho como modelo experimental. Acta Sci Vet 2013;41:1134

34 Morato G. Freeze-dried cancellous bone dog used as pure and graft associated with platelet-rich plasma or bone marrow induced bone defects in rabbits: experimental study [thesis]. Jaboticabal: Faculdade de Ciências Agrárias e Veterinárias, Universidade Estadual Paulista Júlio de Mesquita Filho; 2013

35 Dhurat R, Sukesh M. Principles and methods of preparation of platelet-rich plasma: A review and author's perspective. J Cutan Aesthet Surg 2014;7(04):189-197 